УДК 338.43:332.1

DOI: $10.25140 / 2411-5215-2019-4(20)-204-218$

Олег Рассказов

\title{
ВПЛИВ АГРОПРОМИСЛОВИХ КОМПЛЕКСІВ НА РОЗВИТОК СІЛЬСЬКИХ ТЕРИТОРІЙ
}

\author{
Олег Рассказов \\ ВЛИЯНИЕ АГРОПРОМЫШЛЕННЫХ КОМПЛЕКСОВ \\ НА РАЗВИТИЕ СЕЛЬСКИХ ТЕРРИТОРИЙ \\ Oleg Rasskazov

\section{THE INFLUENCE OF AGRICULTURAL COMPLEXES ON THE DEVELOPMENT OF RURAL AREAS}

\begin{abstract}
Стаття присвячена вивченню питань щодо визначення впливу та ролі агропромислового виробниитва на розвиток сільських територій із урахуванням раціонального та ефективного використання їхнього потенціалу для підвищення рівня їх функціонування та розвитку. Проведене дослідження показало відсутність стратегії розвитку вищезгаданих процесів та невикористання можливостей створених об'єднаних територіальних громад, які сьогодні отримали перспективи реального впливу на діяльність сільськогосподарських виробництв. 3 огляду на вищезазначене запропоновано при розробиі конщепиї стратегічного розвитку иієї сфери господарювання закласти стратегіі комплексного, сталого та інклюзивного розвитку на основі грунтовних досліджень вихідних положень та основних наукових напрачювань вітчизняних та закордонних учених із досліджуваної теми. Виділено ключові методологічні положення, які мають стати основою при розробиі стратегії розвитку агропромислової сфери.
\end{abstract}

Ключові слова: агропромислове виробництво; сільські території; розвиток сільського господарства; комплексний розвиток; сталий розвиток; інклюзивний розвиток; агропромислова сфера; сільське господарство.

Бібл.: 34.

Статья посвящена изучению вопросов по определению влияния и роли агропромыциленного производства на развитие сельских территорий с учетом рачионального и эффективного использования их потенциала с целью повышение уровня их функиионирования и развития. Проведенное исследование показало отсутствие стратегии развития вышеупомянутых проиессов и неиспользование возможностей созданных объединенных территориальных общин, которые сегодня получили перспективы реального влияния на деятельность сельскохозяйственных производств. Исходя из чего, предложено при разработке концепиии стратегического развития данной сферы хозяйствования заложсть стратегии комплексного, устойчивого и инклюзивного развития на основе фундаментальных исследований исходных положений и основных научных наработок отечественных и зарубежных ученых по данной теме. Выделены ключевые методологические положения, которые должны стать основой при разработке стратегии развития агропромышленной сферы.

Ключевые слова: агропромышленное производство; сельские территории; развитие сельского хозяйства; комплексное развитие; устойчивое развитие; инклюзивный развитие; агропромышленная сфера; сельское хозяйство.

Библ.: 34.

The article deals with the issues of determining the impact and role of agro-industrial production on the development of rural areas, taking into account the rational and effective use of their potential to enhance their functioning and development. The conducted research showed that there was no strategy for the development of the above-mentioned processes and the lack of use of the opportunities created by the united territorial communities, which today received the prospects of a real impact on the activities of agricultural production. Therefore, it is suggested that in developing the concept of strategic development of this sphere of economy, to lay down strategies for integrated, sustainable and inclusive development on the basis of thorough research of the baseline provisions and basic scientific developments of national and foreign scientists on the subject. The key methodological provisions that should be the basis for the development of the agroindustrial development strategy are highlighted.

Keywords: agro-industrial production; rural territories; agricultural development; integrated development; sustainable development; inclusive development; agro-industrial sphere; agriculture.

References: 34.

JEL Classification: O130; Q100

Постановка проблеми. Протягом усього періоду незалежності України держава декларує пріоритетність розвитку аграрної сфери виробництва як ключової ланки економіки країни та сільських територій, як носія потужного потенціалу розвитку сільськогосподарського виробництва та переробної промисловості. Ці проблеми були об'єктом детальної уваги як науковців, так і представників органів влади, що дозволило провести значну кількість теоретичних та прикладних досліджень, а також прийняти низку програм, спрямованих на підвищення ефективності розвитку агропромислового виробництва та відродження українського села. Однак треба зауважити, що незважаю-

(С Рассказов О. I., 2019 
ГАЛУЗЕВИЙ АСПЕКТ РОЗВИТКУ НАЦІОНАЛЬНОГО ГОСПОДАРСТВА

чи на докладені зусилля загального очікуваного позитивного ефекту не було досягнуто, оскільки здебільшого розвиток агропромислового виробництва та сільських територій були різноспрямованими, неузгодженими. Крім того, досягнуті локальні позитивні тенденції досить часто нівелюються погіршенням соціально-економічної та демографічної ситуації в межах сільських територій, посиленням частоти використання методів недосконалої конкуренції, або ж навіть неринкового впливу на розвиток агропромислового виробництва, поширення в ньому форм тінізації тощо.

Аналіз останніх досліджень і публікацій. Питаннями розвитку агропромислового виробництва та сільських територій займалися такі вчені, як М. П. Бутко, І.В.Прокопа, К. І. Якуба， М. Й. Малік， В. В. Юрчишин， А. М. Третяк， В. М. Другак， О. І. Павлов, О. М. Онищенко, П. І. Гайдуцький, М. Кропивка, Б. Панасюк, В. Я. Месель-Веселяк та інші.

Виділення недосліджених частин загальної проблеми. Незважаючи на значний науковий доробок зі зазначеної проблеми, на сьогодні відсутнє сучасне чітке бачення щодо взаємодоповнюючого та взаєморозвиваючого розвитку агропромислового виробництва та сільських територій.

Мета статті. Метою статті є розкриття сутності взаємозв'язку, ролі та впливу агропромислових підприємств на розвиток сільських територій та громад.

Виклад основного матеріалу. Загальним результатом розвитку агропромислового виробництва та сільських територій у таких умовах $є$ подальше накопичення, поглиблення та ускладнення невирішених проблем розвитку сільського господарства та обробної промисловості та формування надзвичайно несприятливих передумов розвитку сільських поселень, які призводять до їх поступової деградації. Причинами поглиблення таких негативних тенденцій $є$ відсутність сучасного чіткого бачення стосовно взаємодоповнюючого та взаєморозвиваючого розвитку агропромислового виробництва та сільських територій.

Так, у своїх дослідженнях I. Прокопа визначає кінцеву мету розвитку сільського господарства як забезпечення продовольчої безпеки й підвищення ефективності виробництва. Водночас головною метою розвитку сільської місцевості дослідник визначав покращення умов життєдіяльності людей, які в ній проживають. Відповідно основними завданнями розвитку сільських територій є істотне збільшення доходів сільського населення, поліпшення соціальної інфраструктури села, підвищення уваги до розвитку найбільш вразливих (проблемних) поселень і територій, вдосконалення системи державного регулювання соціального розвитку села. У цьому підході сільські території несуть, насамперед, соціальне навантаження [1].

Варто відзначити дослідження в К. Якуба, на думку якого сільські населені пункти необхідно розглядати як адміністративно-територіальні одиниці незалежно від їхнього розміру (хутір, село, сільська рада, район тощо) з наявним населенням, природноекономічним і соціальним потенціалом та відповідними органами управління соціально-економічним розвитком цих населених пунктів, а територіально-просторове розміщення їх сукупного ресурсного потенціалу можна вважати територіями. Тобто «сільські території», на відміну від понять «місцевість» і «територія», крім просторовотериторіальної складової, і поняття «село» мають також соціально-економічний зміст природноресурсний і людський (демографічний) потенціал [2].

М. Малік пропонує галузевий підхід до визначення сільської території. За таких умов сільську територію розглядають як сформовану в історично визначених межах системну сукупність, що поєднує в собі організаційно-територіальну (село, район) і територіально-функціональну належність (виробництво, переробка та реалізація сільськогосподарської продукції) [3]. 
ГАЛУЗЕВИЙ АСПЕКТ РОЗВИТКУ НАЦІОНАЛЬНОГО ГОСПОДАРСТВА

Про тісний взаємозв'язок розвитку сільських територій та відповідних сільськогосподарських і переробних виробництв вказує В. Юрчишин. На погляд дослідника, сільські території є однією з великої кількості складових сільськогосподарського виробництва. Кінцевий результат функціонування агропродовольчого сектору економіки безпосередньо залежить від того, як спрацює в цьому відношенні кожна сільська територія. На кожній сільській території об'єднуються конкретні природні, соціальні, економічні, виробничо-господарські, екологічні та інші елементи (складові), взаємодія яких залежно від їх відпрацьованості й рівня практичного прояву формує особливості, характер і соціально-економічну результативність іï функціонування. За критерієм їх величини вони можуть бути мікро- (село), мезо- (район) і макро- (регіон, область) сільськогосподарськими утвореннями, кожне з яких характеризується сукупністю властивих йому структурних, функціональних та інших характеристик [4].

Багато досліджень розвитку сільських територій пов'язують цей процес виключно із соціальним аспектами Так, А. Третяк та В. Другак до цієї сфери відносять питання духовного та соціального розвитку, формування та розвитку поселенської мережі, територіальної та соціальної інфраструктури, використання природноресурсного потенціалу, місцевого самоврядування. При цьому питання виробничо-господарського розвитку виносяться за межі категоріального апарату розвитку сільських територій [5].

Значної уваги у взаємозалежності розвитку агропромислового виробництва та сільських територій приділив О. Павлов, який визначав, що «сільські території - це гетерогенне, поліелементне та поліфункціональне утворення з населенням як системоутворюючим елементом. Вони складаються з природних, соціальних, виробничо-господарських, політичних складових, які перебувають під управлінським впливом владних інститутів, бізнесових структур та громадських організацій. У просторовому відношенні сільські території виступають як загальнодержавна система, яка має регіональний (макро-), локальний (мезо-) та низовий (мікро-) рівні». Дослідник також вказував, що, крім сіл як типу поселення, соціально-виробничих, культурно-побутових, а іноді й адміністративних осередків, сільські території включають: населення; сільськогосподарські та інші угіддя поза межами сільських поселень із розташованими на них виробничими об'єктами; органи самоврядування та громадські організації. Поняття ж «сільська місцевість» доцільно використовувати щодо кожного окремого поселенського симплекса [6].

У своїх дослідженнях М. Бутко, О. Онищенко пов'язують розвиток сільських територій з аграрною політикою. На їхню думку, аграрний устрій може розглядатися з позицій відображення в ньому системного прояву суспільно-політичних і соціально-економічних відносин в аграрному секторі, які узгоджуються за стратегічним цільовим призначенням і формами прояву із суспільно-політичним устроєм [7; 8]. П. Гайдуцький вказує на те, що нерозмежованість заходів підтримки сільського господарства та сільської території, чого немає в жодній галузі економіки, викривляє реальну картину підтримки аграрного сектору [9]. На підтримку цієї позиції вказують і дослідження М. Кропивка, в яких стверджується, що галузеві та регіональні програми мають бути диференційованими, а розвиток сільських територій повинен вважатися прерогативою органів місцевого самоврядування [10]. У багатьох дослідженнях акцентується увага на застосуванні західноєвропейської моделі використання та благоустрою сільських територій, що грунтується на можливостях багатофункціонального екологічно врівноваженого їх розвитку та передбачає диференціацію сільського й аграрного розвитку [11]. На думку дослідника Б. Панасюка, відродження сільських територій є можливим за умови виведення сільського господарства зі скрутного становища, відновлення його виробничої бази, кооперації сільськогосподарського виробництва 3 переробною промисловістю і торгівлею, розвитку агропідприємств [12]. До цього приєднується думка В. Месель-Веселяка про виключне значення для соціально-економічного розвитку сільських територій реформування земельних відносин i відносин власності в сільському господарстві [13]. 
ГАЛУЗЕВИЙ АСПЕКТ РОЗВИТКУ НАЦІОНАЛЬНОГО ГОСПОДАРСТВА

Враховуючи відсутність сучасних загальноприйнятих підходів до визначення ролі агропромислового виробництва в розвитку сільських територій на основі раціонального використання наявного в їхніх межах ресурсного потенціалу в напрямі підвищення рівня їх соціально-економічного розвитку, треба визнати факт відсутності стратегічного бачення перспективного розвитку цих процесів. Поглиблює цю проблему й відсутність концептуальних засад використання потенціалу створених об'єднаних територіальних громад, які внаслідок передачі на їх рівень значної кількості управлінських повноважень, безпосередньо отримали значні ресурси, можливості та інструменти безпосереднього регулювання взаємодоповнюючого розвитку сільськогосподарських та обробних виробництв. Загалом такий стан формує широкий спектр ризикогенних явищ та процесів, які за умови відсутності системи їх виявлення та запобігання їх негативному розвитку зумовили:

- формування дисбалансів у процесі реалізації інтересів економічних агентів, задіяних у агропромисловому виробництві (сільського населення, бізнесу, місцевих громад, суспільства), що обмежує мотиви до активної діяльності населення, підприємницьких структур, органів місцевого самоврядування;

- відсутність орієнтації на забезпечення потреб сільського населення, що не дає йому можливості забезпечити всебічний розвиток, зростання рівня та якості його життя, що поглиблює проблему бідності та соціального виключення населення сільських територій;

- обмеження можливостей довготривалої та продуктивної зайнятості, яка формує передумови до посилення процесів територіальної та трудової мобільності, наслідком чого може стати обмеження трудоресурсного потенціалу сільських територій;

- переважання сировинного спрямування розвитку сільськогосподарських підприємств, що зумовлює непостійний (сезонний) характер їхньої діяльності та залежність від природних чинників розвитку агровиробництва;

- значне поширення невеликих за розміром агропромислових формувань, які, $з$ одного боку, забезпечують умови якісної конкуренції, а з іншого - через ускладнений доступ до фінансових і матеріальних ресурсів не здатні забезпечити доцільну спеціалізацію виробництва сільськогосподарської продукції, посилення місцевого економічного потенціалу через диверсифікацію сільської економіки;

- відсутність розвиненої інфраструктури виробництва та реалізації продукції сільськогосподарські та обробні підприємства неспроможні отримувати додану вартість та забезпечувати позитивний цикл накопичення й інвестицій, що у свою чергу призводить до обмеження їх результативності через зростання витрат на посередників, переробників, оптових та роздрібних торговців тощо.

Поглиблення визначених ризикогенних явищ та процесів актуалізує необхідність теоретико-методологічних та прикладних засад розвитку сільськогосподарської та переробної ланки АПК та еволюції сільських територій. Такі дослідження повинні стати базисом для формування нової концепції стратегічного розвитку цієї сфери господарювання та повинні здійснюватися, на нашу думку, на основі використання фундаментальних положень, які були сформовані протягом тривалого історичного процесу. 3 огляду на це припущення в основу розробки такої концепції мають бути покладені стратегії:

- комплексного розвитку, метою якої є раціональне використання наявних ресурсів, що спрямоване на зниженні витрат на виробництво та відповідне зростання конкурентоспроможності продукції;

- сталого розвитку, який спрямований на максимально повне задоволення потреб населення з метою його всебічного розвитку.

Теорія комплексного розвитку отримала свій розвиток у середині ХХ століття на теренах колишнього СРСР, як поглиблення теоретичного базису сформульованого дослідниками німецької школи стосовно локалізації виробництва. 
ГАЛУЗЕВИЙ АСПЕКТ РОЗВИТКУ НАЦІОНАЛЬНОГО ГОСПОДАРСТВА

Одне $з$ найперших досліджень із цієї проблеми належить Я. Г. Фейгіну, в якому він намагався застосувати актуальні здобутки дослідник зарубіжних шкіл для тогочасних реалій. У своїх роботах дослідник наголошував, що «велике наукове і практичне значення має правильне визначення основних критеріїв економічної ефективності існуючих і в особливості перспективних спеціалізації та комплексного розвитку господарства економічних районів різного типу. Ці критерії повинні стати важливим мірилом виявлення недоліків у наявній спеціалізації економічних районів, недоліків у справі їх комплексного розвитку, які тягнуть за собою значні втрати, знижують економічну ефективність капітальних вкладень, ефективність використання природних i трудових ресурсів, породжують нераціональні перевезення палива, сировини і готової продукції. Ці критерії виражаються через економічні показники, найбільш важливими з яких є: питомі капітальні вкладення; собівартість продукції в місцях виробництва і районах споживання; термін окупності капіталовкладень; повнота і раціональність використання трудових ресурсів; балансові вимоги» [14, с. 131].

Окремо треба відзначити групування факторів комплексного розвитку, які виділив Я. Г. Фейгін:

1. Природні ресурси. «Роль природних ресурсів у спеціалізації і комплексному розвитку економічних районів визначається рядом факторів: кількісною і якісно характеристикою самих ресурсів, їх розміщенням, а також досягненим рівнем розвитку продуктивних сил країни і рівнем економічного розвитку районів» [14, с. 101].

2. Розміщення населення і трудових ресурсів. «Роль населення в спеціалізації і комплексному розвитку господарства регіонів $\epsilon$ одним із проявів ролі населення в розвитку виробництва загалом, що залежить від багатьох факторів. Головними із них є: a) процеси природного руху, що значною мірою визначають чисельність і структуру населення, а тому й потенціальну можливість його участі в роботі, у розвитку господарства; б) процеси механічного руху населення, що також визначають загальну кількість та склад населення і тим самим роль населення у виробництві» [14, с. 154].

3. Технічний прогрес. «Розвиток продуктивних сил суспільства має кількісний і якісний боки. Кількісний бік відображує збільшення абсолютних розмірів і обсягів усіх елементів, що складають продуктивні сили; якісний бік - зміни їх технічного рівня. У реальному процесі розвитку продуктивних сил ці боки нерозривно пов'язані між собою і обумовлюють один одного. Однак вирішальне значення належить якісним змінам» [143, с. 194].

4. Транспортний фактор. «Важливою умовою підвищення ефективності суспільного виробництва - поглиблення територіального поділу праці, що приводить до росту зв'язків економічних районів. Одним з основних завдань транспорту є забезпечення зростаючих міжрайонних і внутрірайонних перевезень і з найменшими затратами» [13, с. 217].

Поглиблюючи дослідження комплексності та комплексного розвитку відомий дослідник М. М. Некрасов, вказував, що «комплексний розвиток - це гармонійне сполучення спеціалізуючих галузей виробництва з усім комплексом підприємств промисловості, сільського господарства і транспорту в напрямі їх оптимального сполучення на кожному етапі розвитку району» $[15$, с. 41$]$. Основними ознаками комплексності дослідник визначав:

- забезпеченість діючих і створюваних виробництв трудовими, сировинними і енергетичними ресурсами, обладнанням і матеріалами;

- забезпеченість району будівельною базою;

- достатній рівень розвитку виробничої і соціальної інфраструктури;

- централізація і концентрація в економічно ефективних розмірах заготівельних, ремонтних та інших допоміжних і обслуговуючих виробництв;

- раціональне внутрішньорегіональне розміщення виробництв із загальною системою інженерних комунікацій; 
ГАЛУЗЕВИЙ АСПЕКТ РОЗВИТКУ НАЦІОНАЛЬНОГО ГОСПОДАРСТВА

- максимальне використання переваг економіко географічного положення;

- повне використання економічно ефективних видів природних ресурсів [15, с. 52].

Результатами дослідження В. В. Кістанова було визначення комплексного розвитку, як «планомірного, відносно різнобічного й погодженого, безперервно-поступального розвитку господарства на основі раціональної виробничої спеціалізації, що сприяє підвищенню продуктивності суспільної праці в масштабах країни. Тобто він (розвиток) передбачає стійке сполучення, чітку пропорційність, повну взаємозв'язаність галузей і підрайонів, усіх елементів районного господарства, насамперед досягнення його раціональної (на цьому етапі) виробничої і територіальної структури, за наявності ефективних міжрайонних зв'язків. Отже, комплексний розвиток району - це забезпечення найбільшої відповідності його цілісного, спеціалізованого господарства природноекономічним умовам для вирішення загальнодержавних і місцевих завдань. Комплексний розвиток району направлений на постійне цілеспрямоване удосконалення народногосподарського територіального комплексу» [16, с. 34]. На погляд вченого, основними ознаками комплексного розвитку є:

- планомірність формування районного господарства, його відповідність раціональній пропорційності господарства країни;

- найбільш повне економічно виправдане використання всіх (а не окремих) районних ресурсів;

- раціональна галузева й територіальна структура господарства, тобто ії найбільш можлива відповідність природним і господарським умовам;

- провідна роль кількох великих і найбільш ефективних, у масштабі країни, галузей (спеціалізація);

- тісна взаємозв'язаність, збалансованість усіх галузей господарства;

- поступальний висхідний характер розвитку і стійкість комплексу [17, с. 140].

Дослідженням питань комплексного розвитку займались і вітчизняні вчені. Так, П. В. Волобой і В. А. Поповкін у своїх дослідженнях дійшли висновку: «Мета комплексного розвитку економічних районів полягає в досягненні оптимальної структури, що відповідає наявним у районі природним і економічним умовам, у досягненні економічно ефективних масштабів виробництва, що сприяє загалом підвищенню добробуту населення. При цьому формування господарського комплексу району повинно спиратись на його раціональну спеціалізацію в загальнодержавному поділі праці» [18, с. 74].

Відомий український учений М. М. Паламарчук виділяв окремі види комплексності, залежно від форм взаємодії елементів і спільних рис локалізації виробництв: елементарна, галузева, компактно-територіальна, районно-територіальна, функціональна [19, c. 32]. О. І. Шаблій розширив типологію комплексності, що дозволило йому виділити такі іiі типи: елементарна, галузева, міжгалузева, компактно-територіальна, районнотериторіальна, загальнодержавна територіальна та функціональна [20, с. 48].

Заслуговує на увагу дослідження А. А. Спіфанова, який визначав комплексний розвиток як «поступальний розвиток на основі планування та управління, що передбачає комбінування і кооперування на його території систем виробництва 3 метою раціонального використання всіх видів ресурсів, виробничої, а також соціальної інфраструктури в інтересах найбільш повного задоволення потреб населення, 3 урахуванням його раціонального розселення. Комплексний розвиток розглядається як процес розширеного відтворення, що включає виробництво, розподіл, обмін і споживання матеріальних благ та послуг, закономірності якого визначають усі пропорції і взаємозв'язки економічного розвитку регіону, у результаті чого відтворюються як продуктивні сили, так і виробничі відносини» [21, с. 44]. 
ГАЛУЗЕВИЙ АСПЕКТ РОЗВИТКУ НАЦІОНАЛЬНОГО ГОСПОДАРСТВА

Узагальнюючи науковий доробок у сфері комплексного розвитку господарських систем, необхідно зазначити певні важливі моменти. Передусім недоліки сформованих положень зумовлені специфікою суспільного устрою країні, у період існування якої відбувалось їх формування. До таких недоліків, які обмежують можливості сучасного застосування, треба віднести: централізоване вирішення інституціональних питань комплексного розвитку господарюючих суб'єктів, включення загальнодержавних потреб у визначення, формування та функціонування галузей спеціалізації при локалізації виробничих формувань, об'єктивна відсутність узгоджень прав власності, ігнорування ролі органів місцевого самоврядування при вирішенні питань комплексного розвитку.

Однак існування наведених недоліків не знецінює повністю наукові та прикладні результати досліджень у цій сфері. Відповідно, є підстави для формування сучасних методологічних положень комплексного розвитку господарюючих суб'єктів у сфері виробництва агропромислової продукції. По-перше, треба зауважити, що базовою ланкою реалізації стратегії комплексного розвитку мають стати виробничо-господарські утворення мікрорегіонального рівня, що має відповідати мережі об'єднаних територіальних громад. По-друге, зростання ефективності агропромислового виробництва, як галузі національного господарства має забезпечуватись за рахунок кумулятивного ефекту від ефективності розвитку таких локалізованих суб'єктів господарювання. Обов'язковими основними умовами забезпечення ефективного комплексного розвитку мають стати:

- визначення раціональної спеціалізації локалізованих виробничих формувань, що має досягатись за рахунок врахування та раціонального використання наявних ресурсів територій;

- локалізовані виробничі формування мають складатись із кількох господарюючих суб'єктів, які будуть забезпечувати вирощування агрокультур, переробку сільськогосподарської сировини та виробництво готової продукції, з пріоритетом продукції з високою доданою вартістю;

- поступальний розвиток локалізованих виробничо-господарських формувань має опиратись на розвинену мережу оптимальних та взаємовигідних міжрегіональних та міжгалузевих зв'язків, основу якої має складати розвинута транспортно-логістична та ринкова інфраструктура;

- формування надійного інституціонального базису функціонування таких структур, має забезпечити довгостроковий ефект комплексного розвитку;

- основним джерелом регулювання параметрів комплексного розвитку локалізованих виробничих структур мають стати органи місцевого самоврядування, які нині представлені управлінськими структурами ОТГ;

- врегулювання беззаперечних прав власності та їх надійний захист є основним інструментом отримання доходів власників факторів виробництва, задіяних у процесах функціонування локалізованих виробничих формувань агропромислового спрямування.

Виконання цих основних умов дасть можливість знизити витрати на виробництво продукції сільського господарства та переробної промисловості, що забезпечить зростання рівня іiї конкурентоспроможності, результатом чого має стати розширене відтворення суб'єктів, задіяних у цьому виробництві.

Стратегія сталого розвитку отримала свого поширення в результаті формування багатьох проблем, які стали активно проявлятись у вигляді небезпек для сучасного цивілізаційного розвитку людства. Основною причиною виникнення таких проблем стало розбалансування системи виробництва та споживання, внаслідок зростання кількісних та якісних споживчих потреб людей при обмежених ресурсних можливостях виробництва та розподілу товарів і послуг. Реакцією світової спільноти на такий дисбаланс стала розробка політик стосовно продовольчої, сировинної, енергетичної та екологічної без- 
пеки. Проте багатоаспектність прояву таких дисбалансів, їхня суспільна специфіка потребувала розробки комплексної стратегії їх подолання, що стало основним мотивом розробки концепції сталого розвитку. В основу цієї концепції було покладено потреби людини як суспільної та біологічної істоти, задоволення яких має забезпечити ії всебічний розвиток та збереження економічного, соціального та екологічного середовища для розвитку теперішніх та майбутніх поколінь.

Теоретичний базис концепції сталого розвитку були закладені видатними українськими вченими зі світовим ім'ям - С. Подолинським і В. Вернадським.

У своїх дослідженнях С. Подолинський розглядав економічну діяльність 3 позицій закономірностей функціонування природничих та соціальних процесів, що дало можливість сформувати погляди до потенційних можливостей подальшого існування людства на основі поєднання фізичної доктрини про енергію з економічними характеристиками. На основі використання термодинамічних законів збереження енергії, вчений розробив принципово новий підхід до діагностики соціально-економічних систем. Дослідник вважав працю корисною діяльністю, у результаті якої накопичується додаткова енергія як першоджерело формування доданої вартості. С. Подолинський також зробив висновок про те, що тільки суспільство, що здійснює нагромадження і збереження енергії, може розраховувати на сталий розвиток [22].

В. Вернадський розвинув ідею французьких науковців Е. Леруа, П. Тейяра де Шардена та С. Подолинського і виявив важливу систему взаємозв'язків у системі «людина суспільство». Однією з базових ідей теорії В. Вернадського про ноосферу є визнання людини не самодостатньою живою істотою, що живе окремо за своїми законами, вона співіснує всередині природи і становить частину їі. Результатом дослідження історичних аспектів розвитку нашої планети став висновок ученого про те, «що спостерігається перехід біосфери в новий стан - у ноосферу під дією нової геологічної сили, наукової думки людства» [23]. Відомий український учений А. Гальчинський, підсумовуючи ідеї В. Вернадського, вказував, що «консолідуючою основою ноосфери в теорії В. Вернадського $\epsilon$ енергія людини. Вона реалізується як геологічна сила, як енергія науки, людської культури, як креативність, що пов'язана з психічною діяльністю людини, з розвитком їі свідомості та розуму» [24, с. 17].

Введення в наукову сферу терміна «сталий розвиток» пов'язують із роботами Д. Медоуза, який очолював групу дослідників Массачусетського технологічного інституту (США). Ця група провела дослідження довгострокових соціально-економічних і екологічних наслідків глобалізації, що стало основою для підготовки важливої доповіді для «Римського клубу» - «Межі зростання» (The Limits to Growth). У цьому дослідженні проаналізовано та підсумовано тогочасні загальносвітові тенденції зростання чисельності населення, індустріалізації, навантаження на природне середовище, виробництва продовольства та пов'язаного з цим виснаження природноресурсного потенціалу. На основі результатів цього дослідження був зроблений висновок, що протягом наступного століття цивілізація наблизиться до меж зростання, відбудеться несподіване й неконтрольоване зниження чисельності населення та відбуватиметься значний спад виробництва. Однак дослідники припустили, що є можливість змінити визначені негативні тенденції, що дасть змогу перейти до стану економічної, соціальної та екологічної стабільності, що буде «стало розвиватися» в майбутньому. Основою таких можливостей $є$ зміна свідомості людей. У своїй доповіді «Межі зростання» Д. Медоуз і Дж. Форестер звернулись до суспільства із закликом звести матеріальне виробництво та споживання до рівня простого відтворення [25, с. 245]. Запропоновані в цій роботі дослідження викликали широкий резонанс у суспільстві та здійснили значний вплив на подальше формування світоглядних засад сталого розвитку. 
ГАЛУЗЕВИЙ АСПЕКТ РОЗВИТКУ НАЦІОНАЛЬНОГО ГОСПОДАРСТВА

Найбільшого поширення концепція талого розвитку у світі отримала після доповіді тодішнього прем'єр-міністра Норвегії, голови Всесвітньої комісії ООН з навколишнього середовища та розвитку Гру Гарлем Брундтланд. У звіті «Наше спільне майбутнє» комісії $\mathrm{OOH}$, під його керівництвом, зазначалося, що сталий розвиток - це розвиток, який задовольняє потреби теперішнього часу, проте не ставить під загрозу здатність майбутніх поколінь задовольняти свої власні потреби Він має містити в собі дві ключові складові: концепцію потреб і концепцію обмежень, які зумовлені впливом технологічних і соціальних чинників на екологічну здатність задовольнити нинішні і майбутні потреби. Висновки комісії сформували підгрунтя подальших прийнятих рішень, що оприлюднені на конференції ООН з навколишнього середовища і розвитку у Ріо-деЖанейро «Ріо+20».

Великого поширення концепція сталого розвитку набула й у сучасних вітчизняних дослідженнях.

Відомий український науковець Б. Данилишин, визначає сталий розвиток як «економічно, соціально та екологічно збалансований розвиток окремих територій та розташованих на них населених пунктів, спрямований на узгоджене формування їх соціо-, еколого-, економічної складових на основі раціонального використання всіх видів ресурсів (природних, трудових, науково-технічних, інформаційних і т. ін.)» [26, с. 7].

У своїх дослідженнях 3. Герасимчук пропонує розглядати сталий розвиток як «процес забезпечення функціонування територіальної системи із заданими параметрами в певних умовах протягом тривалого проміжку часу, що веде до гармонізації факторів виробництва та поліпшення якості життя сучасних і майбутніх поколінь за умови підтримання і поетапного розширеного відтворення цілісності природного середовища» [27, с. 12].

Варто відзначити дослідження сталого розвитку О. Масловської, на думку якої «з урахуванням об'єктивної різноманітності території держави за рівнем розвитку продуктивних сил, наявними природноресурсними особливостями, мірою трансформації природних геоекосистем, не може бути єдиного, універсального механізму реалізації національної моделі сталого розвитку на всіх управлінських рівнях. Крім того, кожний регіон має свої специфічні передумови та пріоритети переходу на засади сталого розвитку. Тому, за основу розробки національної стратегії сталого розвитку необхідно покласти принцип регіональної індивідуальності, взаємозалежності і взаємозумовленості елементів системи “природа-економіка-соціум” на територіальному рівні» [28, с. 5].

Узагальнюючи фундаментальні глобальні та національні методологічні дослідження концепції сталого розвитку, можна встановити ключові наукові та прикладні положення, які варто використовувати в процесі дослідження функціонування сільськогосподарського виробництва та переробної промисловості як умови розвитку сільських територій:

- ключовим елементом сталого розвитку є досягнення балансу між потребами населення та обсягами виробництва продукції агропромислового комплексу відповідної якості;

- обсяги та якісні параметри попиту на продукцію сільськогосподарського та переробного виробництва формуються за рахунок потреб споживачів у високоякісній та доступній продукції, споживання якої формує сприятливі режими відтворення економічного, соціального та природного потенціалу населення;

- обсяги виробництва агропромислової продукції здійснюються з огляду на відповідні потреби населення та з урахуванням необхідності раціонального використання наявних ресурсів задля досягнення економічної, соціальної та екологічної ефективності діяльності локалізованих виробничих формувань;

- органи влади та місцевого самоврядування використовують доступні їм інструменти стимулювання діяльності виробничо-господарських структур для забезпечення параметрів сталого розвитку відповідних територій. 
ГАЛУЗЕВИЙ АСПЕКТ РОЗВИТКУ НАЦІОНАЛЬНОГО ГОСПОДАРСТВА

Розвиток та посилення людиноцентричних завдань розвитку, виявлення ефективних механізмів розподілу суспільних благ та підвищення рівня і якості життя людей на межі XX-XXI ст. призвели до актуалізації теорій зростання суспільного добробуту та їх трансформацію в теорію інклюзивного розвитку, яка $\epsilon$ новим сучасним підходом до забезпечення ефективного функціонування регіональних господарських систем різного рівня. Базис цієї концепції склали положення, які були розроблені у 2008 р. Комісією 3 росту та розвитку під керівництвом лауреата Нобелівської премії М. Спенса і опубліковані у праці «Звіт про зростання. Стратегії зростання та інклюзивного розвитку» [29]. Подальші дослідження Дж. Гупта дали можливість виділити низку важливих передумов, завдяки визнанню яких стало можливим формування теорії інклюзивного розвитку, що призвело до зростаючої потреби в новому, інклюзивному міжнародному економічному порядку, що дало можливість визначити складові інклюзивного розвитку на місцевому рівні: а) справедливий розподіл вигід розвитку та рівних можливостей; б) економічні можливості для місцевих жителів (продуктивна зайнятість); в) громадська участь; г) охорона навколишнього середовища; д) адаптивна спроможність (пом'якшення потрясінь існування) [30, с. 484].

Новизна концепції зумовила відсутність єдиного трактування та змісту поняття інклюзивного розвитку, про що свідчить аналіз досліджень із цієї проблеми [31]. До найбільш типових визначень інклюзивного розвитку належать:

- сталий швидкий розвиток усіх галузей економіки, що залучає значну частину трудових ресурсів країни і характеризується рівністю можливостей в доступі до ринку (Світовий банк);

- стабільний і всеосяжний з точки зору можливостей працевлаштування; розвиток, який потребує підтримки з боку громадських інститутів для вирішення проблем на ринку праці (Організація економічного співробітництва та розвитку);

- процес забезпечення високого рівня зайнятості, інвестування в освіту, боротьби 3 бідністю, модернізації ринків праці, системи соціального захисту, а також сприяння згуртованості суспільства (Свропейська комісія) [32];

- підвищення темпів зростання за рахунок надання єдиного простору для інвестицій і продуктивної зайнятості населення (Міжнародний валютний фонд).

Зважаючи на позиції забезпечення розвитку сільських територій за умови розвитку виробничо-господарських формувань аграрного спрямування, заслуговують на увагу дослідження вітчизняних дослідників із досліджуваної проблеми.

У дослідженнях, що стосуються сільського розвитку, О. М. Бородіна та I. В. Прокопа дійшли висновку, що «інклюзивним сільським розвитком слід вважати такий розвиток, результатом якого є гарантування та створення сільським жителям умов для: використання у господарській діяльності землі (а не тільки ії продажу) та інших місцевих природних ресурсів; адекватного розподілу результатів економічного зростання в сільському господарстві та інших галузях сільської економіки; участі у суспільному і громадському житті для згуртування громад і захисту прав людини. Він веде до скорочення бідності, подолання економічного, соціального та політичного вилучення людей, які мешкають у сільській місцевості» [33, с. 70-85].

Т. О. Зінчук, яка вказувала, що «враховуючи європейську практику забезпечення якості життя, ефективними заходами із забезпечення інклюзивного розвитку є активне залучення сільського населення до процесів розробки стратегій розвитку сільських територій, збалансування особистих інтересів окремих людей та загальних інтересів локальної громади щодо захисту природного середовища, соціального згуртування та економічного зростання, формування та імплементація інклюзивної моделі розвитку сільських громад, що сприятиме їх зростанню на умовах сталості. У сучасному сприй- 
ГАЛУЗЕВИЙ АСПЕКТ РОЗВИТКУ НАЦІОНАЛЬНОГО ГОСПОДАРСТВА

нятті поняття “сталості” стосується не тільки питань розвитку сільської економіки та збереження навколишнього середовища, а й має соціальний вимір - ступінь задоволення соціальних потреб громад, вирішення проблем соціальної безпеки та соціальної політики» [34, с. 16-22].

У результаті узагальнення результатів наукових досліджень у сфері розвитку агропромислового виробництва та його впливу на розвиток сільських територій можна виділити певні ключові методологічні положення, які мають бути покладені в основу розробки стратегії розвитку в цій сфері:

- економічна діяльність виробничо-господарських структур агропромислового спрямування має орієнтуватись, в першу чергу на задоволення, потреб населення для підвищення рівня та якості його життя;

- потреби населення формуються відповідно до їхнього добробуту, який забезпечується шляхом отримання адекватних доходів від власності на фактори виробництва та зайнятості;

- розвиток місцевих громад має забезпечувати рівність доступу всіх громадян до економічних та неекономічних благ, що сприятиме забезпеченню їх суспільної згуртованості;

- органи самоврядування громад здійснюють створення умов та стимулів для економічного та соціального розвитку людини шляхом формування та забезпечення дотримання системи гарантій індивідуальної участі кожного учасника в усіх сферах життєдіяльності;

- усі учасники процесу розвитку громад сільських територій у свої діяльності мають реалізовувати принцип забезпечення екологічної ефективності для забезпечення сталого розвитку теперішнього й майбутніх поколінь;

- органи державної влади мають створити інституціональну базу для реалізації гарантованих прав усіх учасників розвитку громад.

Висновки і пропозиції. Отже, дослідження сучасного бачення концепцій та стратегій виявило відсутність одностайності в науковій сфері щодо розвитку агропромислового виробництва та його впливу на розвиток громад. Однак ця проблема в сучасних реаліях як розвитку національного господарства, так і всього українського суспільства отримала надзвичайно високий рівень актуальності. Це потребує розробки концепції стратегічного розвитку сільських територій та виробничо-господарських формувань в їх межах 3 метою формування базових умов для виваженого та прискореного розвитку суспільства. На наше переконання, розвиток такої концепції має будуватись на фундаментальних наукових положеннях функціонування агропромислового виробництва та 3 урахування методологічних умов сучасних стратегій економічного, соціального та екологічного розвитку територій.

\section{Список використаних джерел}

1. Прокопа I. В. Соціальні аспекти розвитку сільських територій. Соціально-економічні проблеми розвитку українського села і сільських територій: матеріали сьомих річних зборів Всеукраїнського конгресу вчених економістів-аграрників. Київ, 2005. С. 96.

2. Якуба К. І. Трудовий потенціал сільських територій. Вісник аграрної науки. 2007. № 6. C. $73-75$.

3. Малік М. Й. До питання сталого розвитку сільських територій. Економіка АПК. 2008. № 5. C. 51-58.

4. Юрчишин В. В. Сільські території як системо утворюючі фактори розвитку аграрного сектору економіки. Економіка АПК. 2005. № 3. С. 3-10.

5. Третяк А. М., Другак В. М. Розвиток сільських територій як один з пріоритетів економічної політики держави. Вісник аграрної науки. 2007. № 7. С. 71-74. 
ГАЛУЗЕВИЙ АСПЕКТ РОЗВИТКУ НАЦІОНАЛЬНОГО ГОСПОДАРСТВА

6. Павлов О. І. Теоретико-методологічні засади сучасної парадигми управління сільськими територіями. URL: http://www.nbuv.gov.ua/e-joumals/DUTP/2005-2/txts/region/05poiust.pdf.

7. Butko M., Povna S., Popelo O., Samiilenko G. European Experience of Clustering and Its Adaptation Towards Acceleration of Innovative Development of the Economy of Ukraine. Proceedings of the 6th International Conference on Strategies, Models and Technologies of Economic Systems Management (SMTESM 2019) /Atlantis Press.

8. Онищенко О. М., Юрчишин В. В. Концептуальні проблеми майбутнього українського села і селянства. Соціально-економічні проблеми розвитку українського села і сільських теритоpiŭ: матеріали сьомих річних зборів Всеукраїнського конгресу вчених економістів-аграрників. Київ, 2005. С. 41-50.

9. Гайдуцький П. І. Про основні засади реформування системи державної підтримки сільського господарства та сільської території. Соціально-економічні проблеми розвитку українського села і сільських територій: матеріали сьомих річних зборів Всеукраїнського конгресу вчених економістів-аграрників. Київ, 2005. С. 85-93.

10. Кропивко М. Ф. Організація державного та самоврядного управління розвитком сільських територій. Соціально-економічні проблеми розвитку украӥнського села і сільських теритоpiŭ: матеріали сьомих річних зборів Всеукраїнського конгресу вчених економістів-аграрників. Київ, 2005. С. 120-123.

11. Тьоткін В. І. Удосконалення державної політики соціального розвитку українського села. Соціально-економічні проблеми розвитку українського села і сільських територій: матеріали сьомих річних зборів Всеукраїнського конгресу вчених економістів-аграрників. Київ, 2005. С. 32-41.

12. Панасюк Б. Я. Шлях до відродження села. Соціально- економічні проблеми розвитку українського села $і$ сільських територій: матеріали сьомих річних зборів Всеукраїнського конгресу вчених економістів- аграрників. Київ, 2005. С. 211-217.

13. Месель-Веселяк В. Я. Реформування аграрного сектора України (результати, проблеми). Соціально-економічні проблеми розвитку украӥнського села і сільських територій: матеріали сьомих річних зборів Всеукраїнського конгресу вчених економістів-аграрників. Київ, 2005. C. $182-189$.

14. Фейгин Я. Г. Размещение производства при капитализме и социализме. 2-е изд. Москва, 1958. $552 \mathrm{c}$.

15. Некрасов Н. Н. Проблемы региональной экономики. Москва: Экономика, 1974. 293 с.

16. Кистанов В. В. Комплексное развитие и специализация экономических районов СССР. Москва: Наука, 1968. 281 с.

17. Кистанов В. В. Территориальная организация производства (отраслевой, районный и народнохозяйственный аспекты). Москва: Экономика, 1981. 232 с.

18. Волобой П. В., Поповкін В. А. Проблеми територіальної спеціалізації і комплексного розвитку народного господарства Української РСР. Київ: Наукова думка, 1972. 215 с.

19. Паламарчук М. М., Тащук К. О. Территориальная структура промышленного комплекса экономического района. Київ: Наукова думка, 1974. 127 с.

20. Шаблий О. Межотраслевые территориальные системы (проблемы методология и теории). Львов: Вища школа, 1976. 462 с.

21. Спіфанов А. О., Сало І. В. Регіональна економіка: навчальний посібник. Київ: Наукова думка, 1999. 343 с.

22. Подолинський С. Людська праця та ії відношення до розподілу енергії. Українська економічна думка: Хрестоматія / [упоряд., наук. ред. пер., авт. вступ. розд. і біогр. довід. С. М. Злупко]. Київ: Знання, 1998. 215 с.

23. Вернадский В. И. Философские мысли натуралиста. Москва: Наука, 1988. 522 с.

24. Гальчинський А. Принципи ноогенези в контексті вчення В. Вернадського України. Економіка Украӥни. 2010. № 5. С. 16-29.

25. Медоуз Д. Х., Рандерс Й., Медоуз Д. Л. Пределы роста. 30 лет спустя: учеб. пособие для ВУЗов. Москва: Академкнига, 2007. 342 с.

26. Данилишин, Б. М. Про Концепцію переходу України до сталого розвитку. Екологічний вісник. 2009. № 6. С. 6-7. 
ГАЛУЗЕВИЙ АСПЕКТ РОЗВИТКУ НАЦІОНАЛЬНОГО ГОСПОДАРСТВА

27. Герасимчук 3. В., Поліщук Г. В. Стимулювання сталого розвитку регіону: теорія, методологія, практика: монографія. Луцьк: РВВ ЛНТУ, 2011. 516 с.

28. Масловська Л. П. Сталий розвиток продуктивних сил регіонів: теорія, методологія, практика: монографія. Київ: Київ. нац. торг.-екон. ун-т, 2003. 366 с.

29. Machael Spence. The Growth Report: Strategies For Sustained Growth And Inclusive Development. URL: https://www.gsb.stanford.edu/faculty-research/publications/growthreport-strategies-sustained-growth-inclusive-development.

30. Bos K., Gupta J. Inclusive development, oil extraction and climate change: a multilevel analysis of Kenya. International Journal of Sustainable Development \& World Ecology. 2016. № 23:6. P. 482-492.

31. Оліфіренко Л. Д. Методичні підходи до оцінювання ефективності інституціональних змін середовища функціонування агропромислових корпорацій. Вісник Чернігівського національного технологічного університету. Серія «Економічні науки». 2014. № 4 (78). С. 332-339.

32. Europe 2020. A strategy for smart, sustainable and inclusive growth. Brussels, EC, 2010. 34 p. URL: http://ec.europa.eu/europe2020/index_en.htm.

33. Бородіна О. М., Прокопа I. В. Інклюзивний сільський розвиток: науковий дискурс. Економіка і прогнозування: науковий журнал. 2019. № 1. C. 70-85. URL: http://eip.org.ua/docs/ EP_19_1_70_uk.pdf.

34. Зінчук Т. О. Інклюзивна складова розвитку сільських громад. Інтелектуальна економіка в умовах суспільних трансформащій: перспективи публічно-приватного партнерства: матеріали III Міжнародного науково-практичного форуму (27 червня 2017 р.): в 2 ч. Житомир: ЖНАЕУ, 2017. Ч. 1. С. 202.

\section{References}

1. Prokopa, I. V. (2005). Sotsialni aspekty rozvytku silskykh terytorii [Social aspects of rural development]. Proceeding from Sotsialno-ekonomichni problemy rozvytku ukrainskoho sela i silskykh terytorii: materialy somykh richnykh zboriv Vseukrainskoho konhresu vchenykh ekonomistivahrarnykiv - Socio-economic Problems of Development of Ukrainian Village and Rural Territories: Materials of the Seventh Annual Meeting of the All-Ukrainian Congress of Agrarian Scientists (p. 96). Kyiv [in Ukrainian].

2. Yakuba, K. I. (2007). Trudovyi potentsial silskykh terytorii [Labor potential of rural territories]. Visnyk ahrarnoi nauky - Bulletin of Agricultural Science, 6, 73-75 [in Ukrainian].

3. Malik, M. I. (2008). Do pytannia staloho rozvytku silskykh terytorii [On the issue of sustainable development of rural territories]. Ekonomika APK - The Economy of Agro-Industrial Complex, 5, 5158 [in Ukrainian].

4. Yurchyshyn, V. V. (2005). Silski terytorii yak systemo utvoriuiuchi faktory rozvytku ahrarnoho sektoru ekonomiky [Rural territories as system-forming factors of development of agrarian sector of economy]. Ekonomika APK - The Economy of Agro-Industrial Complex, 3, 3-10 [in Ukrainian].

5. Tretiak, A. M., Druhak, V. M. (2007). Rozvytok silskykh terytorii yak odyn z priorytetiv ekonomichnoi polityky derzhavy [Development of rural territories as one of the priorities of the economic policy of the state]. Visnyk ahrarnoi nauky - Bulletin of Agricultural Science, 7, 71-74 [in Ukrainian].

6. Pavlov, O. I. (2005). Teoretyko-metodolohichni zasady suchasnoi paradyhmy upravlinnia silskymy terytoriiamy [Theoretical and methodological foundations of the modern paradigm of rural areas management]. Retrieved from http://www.nbuv.gov.ua/e-joumals/DUTP/2005-2/txts/region/05poiust.pdf.

7. Mykola Butko, Svitlana Povna, Olha Popelo, Galyna Samiilenko. European Experience of Clustering and Its Adaptation Towards Acceleration of Innovative Development of the Economy of Ukraine/ Proceedings of the 6th International Conference on Strategies, Models and Technologies of Economic Systems Management (SMTESM 2019)/Atlantis Press.

8. Onyshchenko, O. M., Yurchyshyn, V. V. (2005). Kontseptualni problemy maibutnoho ukrainskoho sela i selianstva [Conceptual problems of the future Ukrainian village and peasantry]. Proceeding from Sotsialno-ekonomichni problemy rozvytku ukrainskoho sela $i$ silskykh terytorii: materialy somykh richnykh zboriv Vseukrainskoho konhresu vchenykh ekonomistiv-ahrarnykiv - Socio-economic Problems of Development of Ukrainian Village and Rural Territories: Materials of the Seventh Annual Meeting of the All-Ukrainian Congress of Agrarian Scientists (pp. 41-50). Kyiv [in Ukrainian]. 
ГАЛУЗЕВИЙ АСПЕКТ РОЗВИТКУ НАЦІОНАЛЬНОГО ГОСПОДАРСТВА

9. Haidutskyi, P. I. (2005). Pro osnovni zasady reformuvannia systemy derzhavnoi pidtrymky silskoho hospodarstva ta silskoi terytorii [About the basic principles of reforming the system of state support of agriculture and rural territory]. Proceeding from Sotsialno-ekonomichni problemy rozvytku ukrainskoho sela i silskykh terytorii: materialy somykh richnykh zboriv Vseukrainskoho konhresu vchenykh ekonomistiv-ahrarnykiv - Socio-economic Problems of Development of Ukrainian Village and Rural Territories: Materials of the Seventh Annual Meeting of the All-Ukrainian Congress of Agrarian Scientists (pp. 85-93). Kyiv [in Ukrainian].

10. Kropyvko, M. F. (2005). Orhanizatsiia derzhavnoho ta samovriadnoho upravlinnia rozvytkom silskykh terytorii [Organization of state and self-governing management of rural development]. Proceeding from Sotsialno-ekonomichni problemy rozvytku ukrainskoho sela i silskykh terytorii: materialy somykh richnykh zboriv Vseukrainskoho konhresu vchenykh ekonomistiv-ahrarnykiv Socio-economic Problems of Development of Ukrainian Village and Rural Territories: Materials of the Seventh Annual Meeting of the All-Ukrainian Congress of Agrarian Scientists (pp. 120-123). Kyiv [in Ukrainian].

11. Totkin, V. I. (2005). Udoskonalennia derzhavnoi polityky sotsialnoho rozvytku ukrainskoho sela [Improvement of the state policy of social development of the Ukrainian village]. Proceeding from Sotsialno-ekonomichni problemy rozvytku ukrainskoho sela i silskykh terytorii: materialy somykh richnykh zboriv Vseukrainskoho konhresu vchenykh ekonomistiv-ahrarnykiv - Socio-economic Problems of Development of Ukrainian Village and Rural Territories: Materials of the Seventh Annual Meeting of the All-Ukrainian Congress of Agrarian Scientists (pp. 32-41). Kyiv [in Ukrainian].

12. Panasiuk, B. Ya. (2005). Shliakh do vidrodzhennia sela [The way to the revival of the village]. Proceeding from Sotsialno-ekonomichni problemy rozvytku ukrainskoho sela i silskykh terytorii: materialy somykh richnykh zboriv Vseukrainskoho konhresu vchenykh ekonomistiv-ahrarnykiv Socio-economic Problems of Development of Ukrainian Village and Rural Territories: Materials of the Seventh Annual Meeting of the All-Ukrainian Congress of Agrarian Scientists (pp. 211-217). Kyiv [in Ukrainian].

13. Mesel-Veseliak, V. Ya. (2005). Reformuvannia ahrarnoho sektora Ukrainy (rezultaty, problemy) [Reforming the agrarian sector of Ukraine (results, problems)]. Proceeding from Sotsialnoekonomichni problemy rozvytku ukrainskoho sela i silskykh terytorii: materialy somykh richnykh zboriv Vseukrainskoho konhresu vchenykh ekonomistiv-ahrarnykiv - Socio-economic Problems of Development of Ukrainian Village and Rural Territories: Materials of the Seventh Annual Meeting of the All-Ukrainian Congress of Agrarian Scientists (pp. 182-189). Kyiv [in Ukrainian].

14. Feihyn, Ia. G. (1958). Razmeshchenie proizvodstva pri kapitalizme i sotsializme [Placement of production under capitalism and socialism] (2nd ed.). Moscow [in Russian].

15. Nekrasov, N. N. (1974). Problemy regionalnoi ekonomiki [Problems of the regional economy]. Moscow: Ekonomika [in Russian].

16. Kistanov, V. V. (1968). Kompleksnoe razvitie $i$ spetsializatsiia ekonomicheskikh raionov SSSR [Integrated development and specialization of economic regions of the USS]. Moscow: Nauka [in Russian].

17. Kistanov, V. V. (1981). Territorialnaia organizatsiia proizvodstva (otraslevoi, raionnyi $i$ narodnokhoziaistvennyi aspekty) [Territorial organization of production (industry, district and national economic aspects)]. Moscow: Ekonomika [in Russian].

18. Voloboi, P. V., Popovkin, V. A. (1972). Problemy terytorialnoi spetsializatsii i kompleksnoho rozvytku narodnoho hospodarstva Ukrainskoi RSR [Problems of territorial specialization and complex development of the national economy of the Ukrainian SSR]. Kyiv: Naukova dumka [in Ukrainian].

19. Palamarchuk, M. M., Tashchuk, K. O. (1974). Territorialnaia struktura promyshlennogo kompleksa ekonomicheskogo raiona [Territorial structure of industrial complex of economic district]. Kyiv: Naukova dumka [in Russian].

20. Shablii, O. (1976). Mezhotraslevye territorialnye sistemy (problemy metodologiia i teorii) [Crosssectoral territorial systems (problems of methodology and theory)]. Lvov: Vyshcha shkola [in Russian].

21. Yepifanov, A. O., Salo, I. V. (1999). Rehionalna ekonomika [Regional economy]. Kyiv: Naukova dumka [in Ukrainian]. 
ГАЛУЗЕВИЙ АСПЕКТ РОЗВИТКУ НАЦІОНАЛЬНОГО ГОСПОДАРСТВА

22. Podolynskyi, S. (1998). Liudska pratsia ta yii vidnoshennia do rozpodilu enerhii [Human labor and its relation to the distribution of energy]. In S. M. Zlupko (Ed.), Ukrainska ekonomichna dumka: Khrestomatiia - Ukrainian Economic Thought: Reader (pp. 215). Kyiv: Znannia [in Ukrainian].

23. Vernadskyi, V. I. (1988). Filosofskie mysli naturalista [The philosophical thoughts of the naturalist]. Moscow: Nauka [in Russian].

24. Halchynskyi, A. (2010). Pryntsypy noohenezy v konteksti vchennia V. Vernadskoho Ukrainy [Principles of noogenesis in the context of the teaching of V. Vernadsky Ukraine]. Ekonomika Ukrainy - Economy of Ukraine, 5, 16-29 [in Ukrainian].

25. Medouz, D. Kh., Randers, I., Medouz, D. L. (2007). Predely rosta. 30 let spustia [Growth limits. 30 years later]. Moscow: Akademkniga [in Russian].

26. Danylyshyn, B. M. (2009). Pro Kontseptsiiu perekhodu Ukrainy do staloho rozvytku [On the Concept of Transition of Ukraine to Sustainable Development]. Ekolohichnyi visnyk - Ecological Bulletin, 6, 6-7 [in Ukrainian].

27. Herasymchuk, Z. V., Polishchuk, H. V. (2011). Stymuliuvannia staloho rozvytku rehionu: teoriia, metodolohiia, praktyka [Stimulating sustainable development of the region: theory, methodology, practice]. Lutsk: RVV LNTU [in Ukrainian].

28. Maslovska, L. P. (2003). Stalyi rozvytok produktyvnykh syl rehioniv: teoriia, metodolohiia, praktyka [Sustainable development of the productive forces of the regions: theory, methodology, practice]. Kyiv: Kyiv. nats. torh.-ekon. un-t [in Ukrainian].

29. Machael, Spence (2008). The Growth Report: Strategies For Sustained Growth And Inclusive Development. Retrieved from https:/www.gsb.stanford.edu/faculty-research/publications/growthreport-strategies-sustained-growth-inclusive-development.

30. Bos, K., Gupta, J. (2016). Inclusive development, oil extraction and climate change: a multilevel analysis of Kenya. International Journal of Sustainable Development \& World Ecology, 23:6, 482-492.

31. Olifirenko, L. D. (2014). Metodichni pidhodi do ocinyuvannya efektivnosti institucional'nih zmin seredovischa funkcionuvannya agropromislovih korporacii [Institualization of the Components of the Governances Mechanism of State Regulation of the Development of Agroindustrial Corporation]. Visnik Chernihivskoho natsionalnoho tehnolohichnoho universitetu. Seriia «Ekonomichni nauky» - Visnyk of Chernihiv State Technological University. Series "Economics», 4(78), 332-339 [in Ukrainian].

32. Europe 2020. A strategy for smart, sustainable and inclusive growth. Brussels, EC, 2010. Retrieved from http://ec.europa.eu/europe2020/ index en.htm.

33. Borodina, O. M., Prokopa, I. V. (2019). Inkliuzyvnyi silskyi rozvytok: naukovyi dyskurs [Inclusive rural development: a scientific discourse]. Ekonomika i prohnozuvannia - Economy and forecasting, 1, 70-85. URL: http://eip.org.ua/docs/EP_19_1_70_uk.pdf.

34. Zinchuk, T. O. (2017). Inkliuzyvna skladova rozvytku silskykh hromad [An inclusive component of rural community development]. Proceeding from Intelektualna ekonomika $v$ umovakh suspilnykh transformatsii: perspektyvy publichno-pryvatnoho partnerstva: materialy III Mizhnarodnoho naukovo-praktychnoho forumu - Intellectual Economy in the Context of Social Transformation: Prospects for Public-Private Partnership: Third International Scientific and Practical Forum (June 27, 2017) (Vol. 1, pp. 202). Zhytomyr: ZhNAEU [in Ukrainian].

Рассказов Олег Ігорович - аспірант кафедри менеджменту та державної служби, Чернігівський національний технологічний університет (вул. Шевченка, 95, м. Чернігів, 14035, Україна).

Рассказов Олег Игоревич - аспирант кафедры менеджмента и государственной службы, Черниговский национальный технологический университет (ул. Шевченко, 95, г. Чернигов, 14035, Украина).

Rasskazov Oleg - PhD student of Management and Public Administration, Chernihiv National University of

Technology (95 Shevchenka Str., 14035 Chernihiv, Ukraine).

E-mail: rasskazovoleg1516@gmail.com

Рассказов О. Вплив агропромислових комплексів на розвиток сільських територій. Проблеми і перспективи економіки та управління. 2019. № 4 (20). С. 204-218. 